\title{
Shift in benthic assemblages and organisms' diet at salmon farms: community structure and stable isotope analyses
}

\author{
Myriam D. Callier ${ }^{1,2, *}$, Sébastien Lefebvre ${ }^{3}$, Mary K. Dunagan $^{2}$, \\ Marie-Paule Bataille ${ }^{4}$, Jennifer Coughlan ${ }^{2}$, Tasman P. Crowe ${ }^{2}$ \\ ${ }^{1}$ Ifremer, Département Ressources Biologiques et Environnement, Unité Biologie des Organismes Marins Exploités,
Station de Palavas, UMR 5119 ECOSYM, Chemin de Maguelone, 34250 Palavas-les-Flots, France
${ }^{2}$ School of Biology and Environmental Science, University College Dublin, Belfield, Dublin 4, Ireland
${ }^{3}$ Université de Lille 1 sciences et technologies, Station Marine de Wimereux,
UMR CNRS 8187 LOG Laboratoire d'Océanologie et Géosciences, 28 av. Foch, 62930 Wimereux, France
${ }^{4}$ UMR INRA 950 EVA, Institut de Biologie Fondamentale et Appliquée, Université de Caen, 14032 Caen, France
}

ABSTRACT: The extent of the influence of salmon farming on the environment and on the uptake of particulate and dissolved effluents by benthic organisms was assessed using community structure and stable isotope analyses. Sediment cores were collected in 2 directions: perpendicular and parallel to the main residual current, 0, 25 and $200 \mathrm{~m}$ from 2 salmon farms (Millstone and Cranford) located in Mulroy Bay, Ireland. In addition, artificial substrates were placed for $2 \mathrm{mo}$ at $1 \mathrm{~m}$ depth 0, 25 and $200 \mathrm{~m}$ from one farm to trace the uptake of farm-related nutrients by fouling organisms. The extent of measurable change in benthic communities (abundance, diversity, structure, trophic composition) depended on residual current direction. Intraspecific variation in isotopic values in benthic invertebrates was mostly explained by distance from cages. Organisms collected at impacted sites exhibited a shift in isotopic composition towards that of farm wastes. A shift in $\delta^{13} \mathrm{C}$ was observed in several invertebrates, including the polychaetes Malacoceros fuliginosus and Nephtys hombergii, Nematoda and the anemone Anthopleura balii. Fouling communities collected on artificial structures, mainly composed of the tunicate Ascidiella aspersa, showed higher $\delta^{15} \mathrm{~N}$ values at fish cage sites compared to sites $200 \mathrm{~m}$ away. The study demonstrated that fish effluents were assimilated and became food sources for several organisms.

KEY WORDS: Aquaculture - Organic matter - Stable isotope $\cdot$ Community structure $\cdot$ Diet shift · Trophic structure

Resale or republication not permitted without written consent of the publisher

\section{INTRODUCTION}

Aquaculture now contributes almost $50 \%$ of the global aquatic food supply. As the demand for aquatic food is increasing, the sustainable development of aquaculture is crucial to contribute to food safety, community development and to reduce overexploitation of natural aquatic resources (FAO 2010). Today, most aquaculture activities are located in coastal areas, where anthropogenic pressures are already high. A better understanding of aquaculture-envi- ronment interactions is therefore needed to determine the environmental carrying capacity of coastal areas for on-going and future aquaculture operations (McKindsey et al. 2006).

Benthic marine food webs are an important component of coastal ecosystems as they contribute to organic matter recycling, linking the pelagic and benthic compartments through various processes (e.g. feeding and bioturbation) (Herman et al. 1999). However, little is known about how changes in biodiversity affect these processes and the extent to which 
ecosystems can absorb and recover from recurrent stresses (Hughes et al. 2005). The introduction of cultured species into the ecosystem may influence trophic interactions by locally modifying the sources of natural food (Lefebvre et al. 2009). One of the predominant environmental impacts related to fish farming is the accumulation of faeces and uneaten food under cages that may lead to organic enrichment of the sea bottom and water column. Organic enrichment may have profound effects on both pelagic and benthic communities (including macrofauna, meiofauna, phytoplankton, seagrasses and bacteria) by modifying: (1) the physico-chemical characteristics of the sediment or water (e.g. decrease in oxygen, change in nutrient ratio, sulphate reduction leading to sulphide accumulation; see review by Hargrave 2005) and (2) the quality and quantity of food sources for auto- and heterotrophic organisms (Dubois et al. 2007a). Most of the waste from aquaculture $(70 \%$ of nitrogen waste for fish farms; Lefebvre et al. 2001) is released into the water column as dissolved nutrients. The remainder (between 5 and $30 \%$ of nitrogen waste) is released as particulate organic matter (POM). POM may be ingested by consumers, such as heterotrophic bacteria, invertebrates and fish, and the dissolved component may enter the food web by being assimilated by autotrophs such as cyanobacteria, phytoplankton and macroalgae (Pitta et al. 2009). Although numerous studies have documented the effects of organic enrichment due to fish farming on biodiversity and community structure (see review by Hargrave 2005), little has been done to understand the assimilation of fish waste into the biota and its effects on trophic interactions between organisms and the food web (Sarà et al. 2004). Shifts in benthic communities along a gradient of organic enrichment may be caused by the loss of sensitive species due to change in environmental conditions and/or the enhancement of opportunistic species, which may benefit from these novel food sources.

Stable isotope analysis is increasingly being used to study the pathways of organic matter in food webs and to determine the contributions of various food sources to organisms' diets (Dubois et al. 2007a). In fish aquaculture studies, natural stable isotopes can be efficient tracers if the particulate waste (faeces and uneaten food) present intrinsic characteristics that clearly differ from the natural environment (Kutti et al. 2007a) and if the local environment is not influenced by other terrestrial inputs (Vizzini \& Mazzola 2004, Dolenec et al. 2007). Nutrients and organic material derived from fish waste are generally enriched in ${ }^{15} \mathrm{~N}$ and depleted in ${ }^{13} \mathrm{C}$ (Mazzola \& Sarà
2001). Cultured carnivorous fish, such as salmon, are high-level predators and are thus fed with animal products such as fish meal, fish oil and crustacean meal. The flesh and wastes of farmed fish are usually enriched in ${ }^{15} \mathrm{~N}$ because of trophic step fractionation (natural enrichment of heavy isotopes along the trophic web) (Yokoyama et al. 2009). In addition, $\delta^{13} \mathrm{C}$ may be used as a tracer (Yokoyama \& Ishihi 2007) as feed pellets are not only composed of fish, but of terrestrial vegetables depleted in ${ }^{13} \mathrm{C}$ (such as wheat and soya bean). Moreover, due to isotopic discrimination against ${ }^{12} \mathrm{C}$ during feeding, lighter ${ }^{12} \mathrm{C}$ is preferentially excreted with respect to the heavier ${ }^{13} \mathrm{C}$ isotope (Michener \& Schell 1994). Benthic filter-feeders are able to feed on material derived from fish faeces (Lefebvre et al. 2000), and the use of natural $\delta^{13} \mathrm{C}$ and $\delta^{15} \mathrm{~N}$ tracers has shown that POM from aquaculture wastes may be incorporated into the food chain by both suspension-feeders (Lojen et al. 2005) and deposit-feeders that process sediments (Dubois et al. 2007a). Dolenec et al. (2007) created a geochemical map of $\delta^{15} \mathrm{~N}$ values in POM and selected invertebrates, and were able to trace the dispersal of ${ }^{15} \mathrm{~N}$ loading generated by aquaculture and sewage and its subsequent incorporation into the adjacent biota. Vizzini \& Mazzola (2006) have suggested that benthic sessile species are better indicators of point-source pollution than nectobenthic ones (fish around cages) which disperse incorporated wastes over larger spatial scales. Some studies have also shown that species changed their trophic behaviour directly because of shellfish aquaculture particulate wastes (Dubois et al. 2007a). From a management perspective, there is a need to evaluate the efficiency of quantitative and qualitative indices such as stable isotopes to detect the extent of influence of fish farms on the environment.

The objective of the study was to evaluate the fate of aquaculture-related organic loading by combining analyses of community structure and $\delta^{13} \mathrm{C}$ and $\delta^{15} \mathrm{~N}$ isotopic signatures. Specifically, we assessed: (1) the spatial variation in macrofaunal diversity, abundance, community structure and the biotic index $\mathrm{M}$ AMBI under and around 2 salmon farms to evaluate the extent of salmon farm impacts; (2) the inter- and intraspecific variation in isotopic values of invertebrates at impacted and non-impacted sites to determine whether species were benefiting from salmon waste as a food source; and (3) the transfer of particulate and dissolved nutrients generated by aquaculture into naturally occurring benthic species and fouling organisms growing on artificial structures, using natural isotopic $\left(\delta^{13} \mathrm{C}\right.$ and $\left.\delta^{15} \mathrm{~N}\right)$ abundance. 


\section{MATERIALS AND METHODS}

\section{Study sites and sampling design}

The study sites were located in Mulroy Bay-a fully marine, fjordic inlet, situated on the northern coast of Co. Donegal, Ireland (Fig. 1). Production levels of Atlantic salmon within Mulroy Bay are $\sim 800$ to $900 \mathrm{t} \mathrm{yr}^{-1}$. The study was done at 2 farms, Millstone (M) and Cranford (C), to assess the generality of any observed patterns. It was expected that the extent of influence of the farms would be greater in the direction of the main water current due to the dispersion of farm waste, as shown by previous studies using a hydrodynamic model such as DEPOMOD (Cromey et al. 2002). To test this hypothesis, sampling was done along 2 separate transects perpendicular (T1) and parallel (T2) to the main water current direction, at distances of 0,25 and $200 \mathrm{~m}$ from the fish cages (12 stations in total). The effects related to the accumulation of faeces and uneaten food under cages are generally limited to within $200 \mathrm{~m}$ of the farm (Mayor et al. 2010). Farfield effects are usually difficult to detect due to the dispersion and dilution of dissolved nutrients by currents (Hargrave 2003, Modica et al. 2006). In the present study, we focused on the near-field effects of fish farms on the benthic environment and

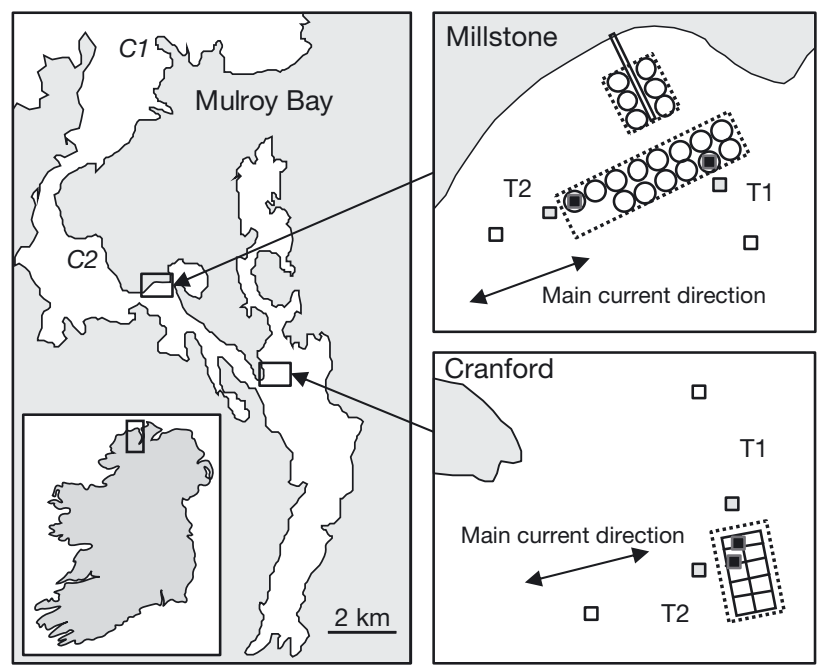

Fig. 1. Locations of the 2 farms studied: Millstone and Cranford, in Mulroy Bay, Co. Donegal, Ireland. Sampling sites

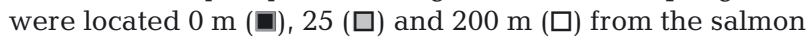
cages (open symbols enclosed in dotted rectangles), in 2 directions: perpendicular (T1) and parallel (T2) to the main water current direction. Map of Mulroy Bay adapted from Telfor \& Robinson (2003). Macroalgae were collected at sites located $>2 \mathrm{~km}$ from the salmon farms (C1 and C2) fouling communities, known as integrators of environmental variation. Water depth in the sampling area ranged from 8 to $10 \mathrm{~m}$. The study was done in the summer of 2009, when the effects of local organic enrichment related to salmon farming operation were likely to have been maximal due to increased salmon production rates on the farms, organic matter deposition and increased water temperature, which may enhance mineralisation rates and thus benthic oxygen demand. We sampled potential sources of particulate nutrients (salmon feed pellets, salmon faeces, cage deposit, macroalgae), the water column and sediments (POM and sedimentary organic matter [SOM]) and the potential consumers (benthic organisms, fouling organisms).

\section{Potential sources of particulate nutrients}

Salmon feed pellets were composed of fish meal, fish oil, wheat, soya bean, crustacean meal and wheat gluten $(30 \%$ oil, $37 \%$ protein, $9 \%$ ash, $1 \%$ fibre, based on the manufacturer's description). Samples of feed pellets (ca. $200 \mathrm{~g}$ ) were randomly collected at the farm in March 2009, June 2009 and May 2010 to evaluate the average feed pellet isotopic ratios and the seasonal variation between stocks. Salmon at both farms were fed with the same feed pellet stock. To determine the composition of salmon faeces, 2 salmon were sacrificed in March and July 2009 to collect their gut contents. Faeces were rinsed with filtered seawater to remove mucus as it may influence the isotopic ratios. Isotopic analyses were performed on both faeces with mucus and rinsed faeces. Data from March 2009 could not be used as the fish had been starved for several days before the sampling, which may have modified the faeces stable isotope ratios. To determine cage deposit composition (including uneaten feed pellets, salmon faeces plus faeces of fouling organisms and any other organic material drifting down from the farm or the surrounding areas), 2 sediment traps were placed under 2 random salmon cages for $24 \mathrm{~h}$. Although faeces and deposit values should be interpreted with care as they represent only a snapshot measure, they are valuable data and may be interpreted in relation to the feed pellet composition. Macroalgae, including Ulva sp., Fucus sp. and Laminaria sp. were collected by hand on the rocky shore in Mulroy Bay at sites not influenced by the farms ( $>2 \mathrm{~km}$ away), as macroalgae settling to the bottom may be a source of organic matter for benthic invertebrates. 


\section{Benthic community characteristics}

In July 2009, sediment samples $(\mathrm{n}=3$ ) were collected by divers using a PVC corer $(11 \mathrm{~cm}$ in diameter) at each station to determine characteristics of the benthic community (total abundance, diversity, structure, trophic composition). Samples were gently sieved through a $500 \mu \mathrm{m}$ mesh. Organisms were sorted, identified, cleaned of epibionts and kept alive for $24 \mathrm{~h}$ in filtered seawater to evacuate their gut content before isotopic analysis (see 'Stable isotope analyses'). Infaunal specimens were stored in a freezer at $-20^{\circ} \mathrm{C}$ until analysed. The remaining material was fixed in a $5 \%$ formaldehyde-saline solution and then stored in $70 \%$ ethanol. Identification was done to the lowest taxonomic level possible, usually to species. Sites were characterised in terms of total abundance, diversity (number of species per site $[S]$ and Shannon-Wiener diversity index $\left.\left[H^{\prime}\right]\right)$ and multivariate community structure (see 'Statistical analysis'). Species were separated into trophic groups according to the classification available in the literature (Fauchald \& Jumars 1979, Word 1990). The AZTI marine biotic index (MAMBI) was used to evaluate the ecological quality of the macrofaunal communities. This index was developed in Europe and is now used worldwide (Muxika et al. 2007, Callier et al. 2008), thus showing its wide applicability. Each identified species is classified into 1 of 5 ecological groups, based on their sensitivity/tolerance to pollution (Borja \& Muxika 2005). The organisms thus classified were used to calculate the AMBI biotic index (software AMBI 5.0). Subsequently, the AMBI index was combined with richness and Shannon Wiener index to give the multivariate biotic index M-AMBI (Muxika et al. 2007) and to determine the ecological quality status (high, good, moderate, poor or bad status). In the present study, sampling stations with a good/ high status were considered as 'non-impacted' and poor/bad status as 'impacted'.

The same specimens collected for the analysis of benthic communities were used for stable isotope analysis. To ensure an adequate biomass of each infaunal species was collected and to sample epibenthic species, a second sampling was done $4 \mathrm{wk}$ later by collecting 2 grab samples at the same 12 stations. In the laboratory, the organisms were cleaned of epibionts and kept alive for several hours in filtered seawater from the sampling areas to evacuate their gut contents. For abundant and small species, individuals from the same replicate were combined, as the present study was focussing on small-spatial scale differences within a species related to aquaculture effluents and not on differences between individuals of a single species.

\section{Fouling organisms}

To evaluate whether farm-derived nutrients (dissolved and particulate) were assimilated by the fouling communities, artificial structures (stone tiles attached to plastic mesh cylinders suspended from a buoy) were deployed at $1 \mathrm{~m}$ water depth at Millstone, 0,25 and $200 \mathrm{~m}$ along the T1 transect for $71 \mathrm{~d}$ (from 3 April 2009 to 23 June 2009). At each distance, 3 structures covered with 6 tiles were placed. Early colonising species were collected 2 mo after deployment. At a distance of $200 \mathrm{~m}, 2$ structures were lost. For this station, variation was therefore calculated on the 6 tiles from the 1 remaining structure. Tiles were frozen separately, and fouling organisms growing on the inner and outer sides of each tile were then sorted and pooled per tile for isotopic analyses. They were cleaned carefully to remove epibionts before drying and grinding.

\section{Sediment OM and water POM}

Sediment samples $(n=2)$ were collected at each station by divers using a cut-off $30 \mathrm{ml}$ plastic syringe. Total carbon and nitrogen content and isotopic composition of the surficial $(0$ to $1 \mathrm{~cm}$ ) and deeper (1 to $5 \mathrm{~cm}$ ) sediment layers were analysed separately.

Water POM was collected at each station (4 l water sample) at $8 \mathrm{~m}$ depth. Extra water samples were collected at $1 \mathrm{~m}$ depth along the transect (Millstone-T1) where artificial structures were deployed. After collection, water samples were prefiltered through a $200 \mu \mathrm{m}$ mesh to remove the largest particles, then filtered onto pre-weighed, pre-combusted $\left(450^{\circ} \mathrm{C}, 4 \mathrm{~h}\right)$ Whatmann GF/C filters. Filters were then freeze-dried until subsequent stable isotope analysis.

\section{Stable isotope analyses}

Before isotopic analysis, sediment samples, GF/C filter and sampled calcareous organisms were divided into 2 subsamples. Subsamples of sediment and calcareous organisms were treated with $1 \mathrm{~N} \mathrm{HCl}$ $(12 \mathrm{~h})$ to remove inorganic carbon and were used for ${ }^{13} \mathrm{C}$ analyses. These were then rinsed with distilled 
water to remove the acid. GF/C filters were treated with concentrated $\mathrm{HCl}$ flumes to remove carbonates (Lorrain et al. 2003). Subsamples for isotopic nitrogen analyses were not decarbonated because this has been reported to affect the $\delta^{15} \mathrm{~N}$ and total organic $\mathrm{N}$ values (Ryba \& Burgess 2002).

Freeze-dried, powdered and homogenised samples were analysed using a CHN elemental analyser (EA 3000, EuroVector, Université de Caen BasseNormandie) for particulate organic carbon and particulate nitrogen to calculate their $\mathrm{C} / \mathrm{N}$ atomic ratios. Analytical precision for the experimental procedure was estimated to be better than $0.01 \%$ dry weight for $\mathrm{C}$ and $0.03 \%$ dry weight for $\mathrm{N}$. The resultant gas of elemental analyses was introduced into an isotope ratio mass spectrometer (IRMS) (IsoPrime, Elementar) to determine ${ }^{15} \mathrm{~N} /{ }^{14} \mathrm{~N}$ and ${ }^{13} \mathrm{C} /{ }^{12} \mathrm{C}$ ratios. Stable isotopic values are expressed as the relative differences (in \%) between the samples and the conventional standards, Pee Dee Belemnite (PDB) for carbon and atmospheric $\mathrm{N}_{2}$ for nitrogen, according to the following equation: $\delta=\left[\left(R_{\text {sample }} / R_{\text {standard }}\right)-1\right] \times 1000$, where $\delta$ is ${ }^{13} \mathrm{C}$ or ${ }^{15} \mathrm{~N}$ relative abundance (in \%o) regarding the conventional standard and $R$ is the ${ }^{13} \mathrm{C} /{ }^{12} \mathrm{C}$ or ${ }^{15} \mathrm{~N} /{ }^{14} \mathrm{~N}$ ratio. The internal standard was the USGS 40 of the International Atomic Energy Agency $\left(\delta^{13} \mathrm{C}=-26.2 ; \delta^{15} \mathrm{~N}=-4.5\right)$. The typical precision in analyses was $\pm 0.25 \%$ o for carbon and $\pm 0.40 \%$ for nitrogen isotope ratios.

The carbon and nitrogen isotopic compositions of consumer tissues are thus functions of the ratios of ${ }^{13} \mathrm{C}$ to ${ }^{12} \mathrm{C}\left(\delta^{13} \mathrm{C}\right)$ and ${ }^{15} \mathrm{~N}$ to ${ }^{14} \mathrm{~N}\left(\delta^{15} \mathrm{~N}\right)$ of each assimilated food source. A comparison between stable isotopic compositions of several consumers to estimate their trophic relationships must be made under the strong assumption that trophic step fractionation is accurately estimated for each species. However, very few values of trophic step fractionation are available for marine invertebrates and, as done in most ecological studies using isotopic approaches (e.g. Lefebvre et al. 2009), we assumed that the fractionation values were the same for all species, sites and seasons. Trophic step fractionation values of 1 for $\delta^{13} \mathrm{C}$ and 3.4 for $\delta^{15} \mathrm{~N}$ were chosen. Trophic levels (TL) were calculated using primary consumers. Long-lived primary consumers, such as mussels, satisfy these criteria in aquatic food webs and can provide an appropriate baseline to quantify the trophic position of secondary consumers. We used the equation $\mathrm{TL}_{\text {consumer }}=2+$ $\left(\delta^{15} \mathrm{~N}_{\text {consumer }}-\delta^{15} \mathrm{~N}_{\text {base }}\right) / 3.4$ (van Oevelen et al. 2009), with $\delta^{15} \mathrm{~N}_{\text {base }}=5.1$ corresponding to the Mytilus edulis value collected on pontoons at the entrance to Mulroy Bay (Fig. 1).

\section{Statistical analysis}

Variations in univariate indices (abundance, diversity, sediment $\% \mathrm{C}$ total and $\% \mathrm{~N}$ total, and sediment stable isotope values) were evaluated using ANOVA followed by Tukey's multiple comparison tests with SYSTAT. The normality and homogeneity of variance were tested using the Kolmogorov-Smirnov test and Cochran's test, respectively. ANOVA factors were: farm (2 levels, fixed: Millstone and Cranford), direction (2 levels, fixed: T1 perpendicular and T2 parallel) and distance (3 levels, fixed: 0, 25 and $200 \mathrm{~m}$ from the farm), $n=3$. Non-parametric multivariate analyses of community structure, including multidimensional scaling were performed using PRIMER (Clarke \& Warwick 1994). Analyses were done using individual cores as replicates. Variation in benthic community structure was evaluated using PERMANOVA (a distance-based nonparametric multivariate analogue of ANOVA) (Anderson \& Ter Braak 2003). The level of similarity and the contribution of each species to the total similarity among samples were determined using SIMPER. Data were square-roottransformed for all multivariate analyses to reduce the influence of the dominant taxa, and similarity matrices were based on the Bray-Curtis index of similarity. Based on community analysis, 2 clusters were defined, one containing sites impacted by the salmon farm, the other one containing sites not impacted. For invertebrate stable isotope analysis, the difference between isotopic composition of the species collected both at impacted and non-impacted sites was analysed through ANOVA.

\section{RESULTS}

\section{Potential source of particulate nutrients in the vicinity of salmon farms}

Although feed pellet composition was similar throughout the year, significant variation in nitrogen and carbon isotopic composition was measured in fish feed pellets between the 3 sampling dates (Table $1 ; \delta^{15} \mathrm{~N}$ : March $2009 \neq$ June $2009 \neq$ May 2010, $\mathrm{p}<0.001 ; \delta^{13} \mathrm{C}:$ March $2009 \neq$ June $2009=$ May 2010, $\mathrm{p}=0.002$ ). Compared to other potential sources of organic matter in the environment, fish feed pellets were depleted in ${ }^{13} \mathrm{C}$ and relatively enriched in ${ }^{15} \mathrm{~N}$ (Table 1). Salmon faeces presented similar values for $\delta^{15} \mathrm{~N}$, but lower values for $\delta^{13} \mathrm{C}$ compared to the average $( \pm \mathrm{SD})$ feed pellet composition $(8.8 \pm 1.2 \%$, $-23.0 \pm 0.5 \%$ o). Isotopic values of cage deposits were 
Table 1. Mean $( \pm \mathrm{SD})$ stable isotopic values $\left(\delta^{15} \mathrm{~N}\right.$ and $\left.\delta^{13} \mathrm{C}\right), \% \mathrm{~N}, \% \mathrm{C}$ and $\mathrm{C} / \mathrm{N}$ ratio of salmon farm organic matter and macroalgae. Salmon feed pellets were collected from the feed stock at Millstone and Cranford (same feed used at both farms). Salmon faeces were collected from gutted salmons, and cage deposits from sediment traps deployed beneath Millstone cages for $24 \mathrm{~h}$. Macroalgae were collected in Mulroy Bay at sites located $>2 \mathrm{~km}$ from the farms (C1 for Fucus sp., and C2 for Laminaria sp. and Ulva spp.; see Fig. 1). $\mathrm{n}=$ number of samples

\begin{tabular}{|c|c|c|c|c|c|c|c|}
\hline & Collection date & $\mathrm{n}$ & $\delta^{15} \mathrm{~N}$ & $\% \mathrm{~N}$ & ${ }^{813} \mathrm{C}$ & $\% \mathrm{C}$ & $\mathrm{C} / \mathrm{N}$ \\
\hline \multicolumn{8}{|c|}{ Farm organic matter } \\
\hline Feed pellet & Mar 2009 & 4 & $8.5 \pm 0.3$ & $7.3 \pm 0.3$ & $-23.5 \pm 0.1$ & $51.6 \pm 1.2$ & $7.1 \pm 0.3$ \\
\hline Feed pellet & Jun 2009 & 4 & $7.9 \pm 0.2$ & $6.4 \pm 0.3$ & $-22.6 \pm 0.2$ & $54.6 \pm 1.0$ & $8.5 \pm 0.6$ \\
\hline Feed pellet & May 2010 & 2 & $10.2 \pm 0.3$ & $7.0 \pm 0.5$ & $-22.9 \pm 0.4$ & $51.6 \pm 0.4$ & $7.3 \pm 0.6$ \\
\hline Faeces & Jul 2009 & 3 & $7.9 \pm 0.1$ & $3.1 \pm 1.5$ & $-21.7 \pm 0.2$ & $27.5 \pm 0.1$ & $10.0 \pm 3.7$ \\
\hline Faeces rinsed & Jul 2009 & 2 & $8.6 \pm 0.5$ & $2.1 \pm 0.0$ & $-20.3 \pm 0.0$ & $23.2 \pm 0.5$ & $11.3 \pm 0.0$ \\
\hline Cage deposits & Jul 2009 & 4 & $6.4 \pm 0.8$ & $1.8 \pm 0.2$ & $-22.3 \pm 0.1$ & $23.2 \pm 3.0$ & $12.9 \pm 0.6$ \\
\hline \multicolumn{8}{|l|}{ Macroalgae } \\
\hline \multicolumn{2}{|l|}{ Fucus sp. } & 2 & $6.5 \pm 1.2$ & $1.3 \pm 0.0$ & $-16.7 \pm 0.1$ & $32.5 \pm 0.4$ & $24.5 \pm 0.2$ \\
\hline \multicolumn{2}{|l|}{ Laminaria sp. } & 2 & $4.4 \pm 0.3$ & $0.8 \pm 0.1$ & $-19.4 \pm 0.3$ & $25.5 \pm 0.5$ & $32.0 \pm 3.2$ \\
\hline \multicolumn{2}{|l|}{ Ulva lactuca } & 1 & 4.7 & 3.2 & -18.2 & 30.2 & 9.4 \\
\hline \multicolumn{2}{|c|}{ Enteromorpha (Ulva) sp. } & 1 & 6.3 & 1.8 & -18.8 & 27.2 & 15.5 \\
\hline
\end{tabular}
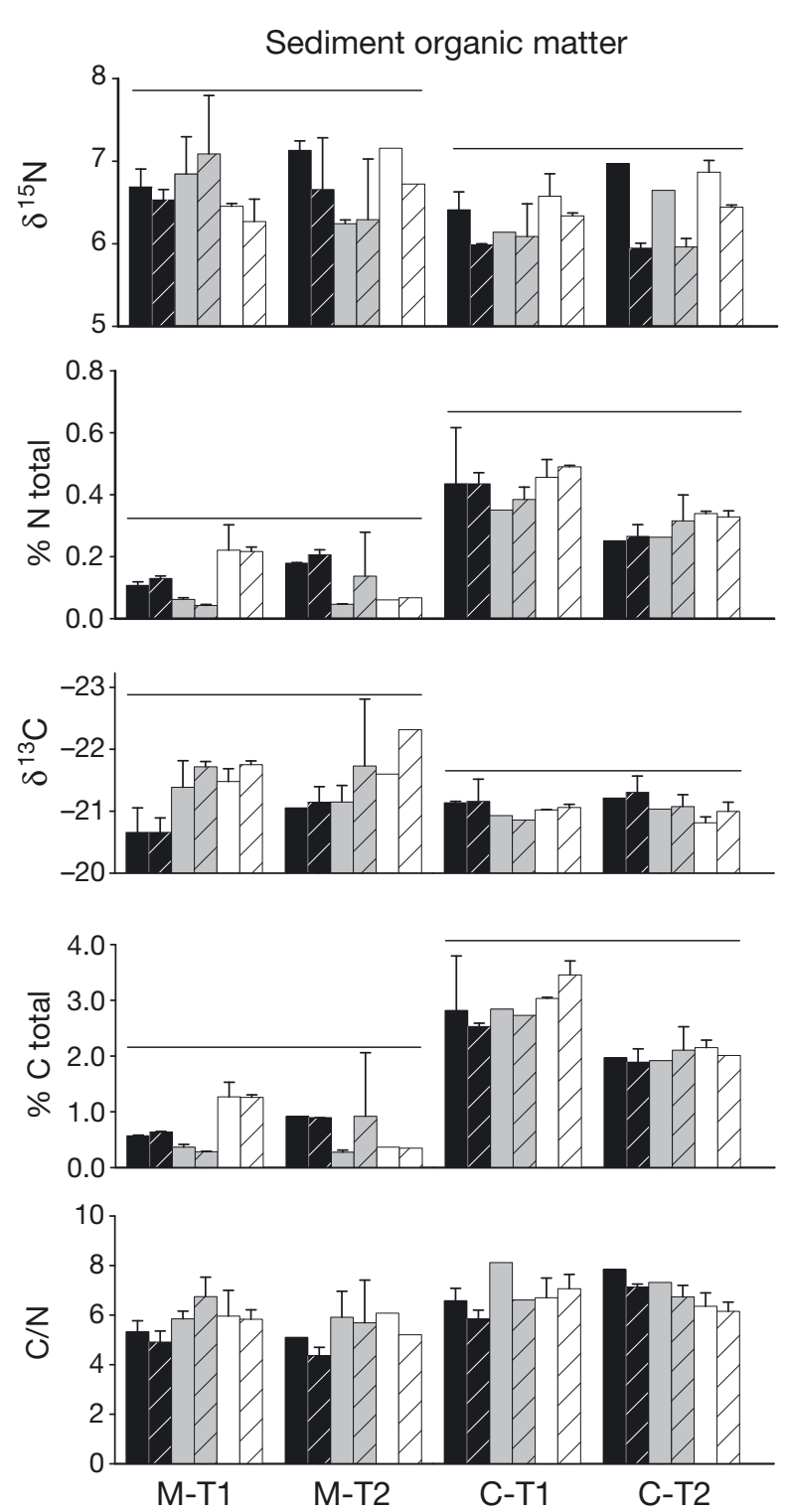
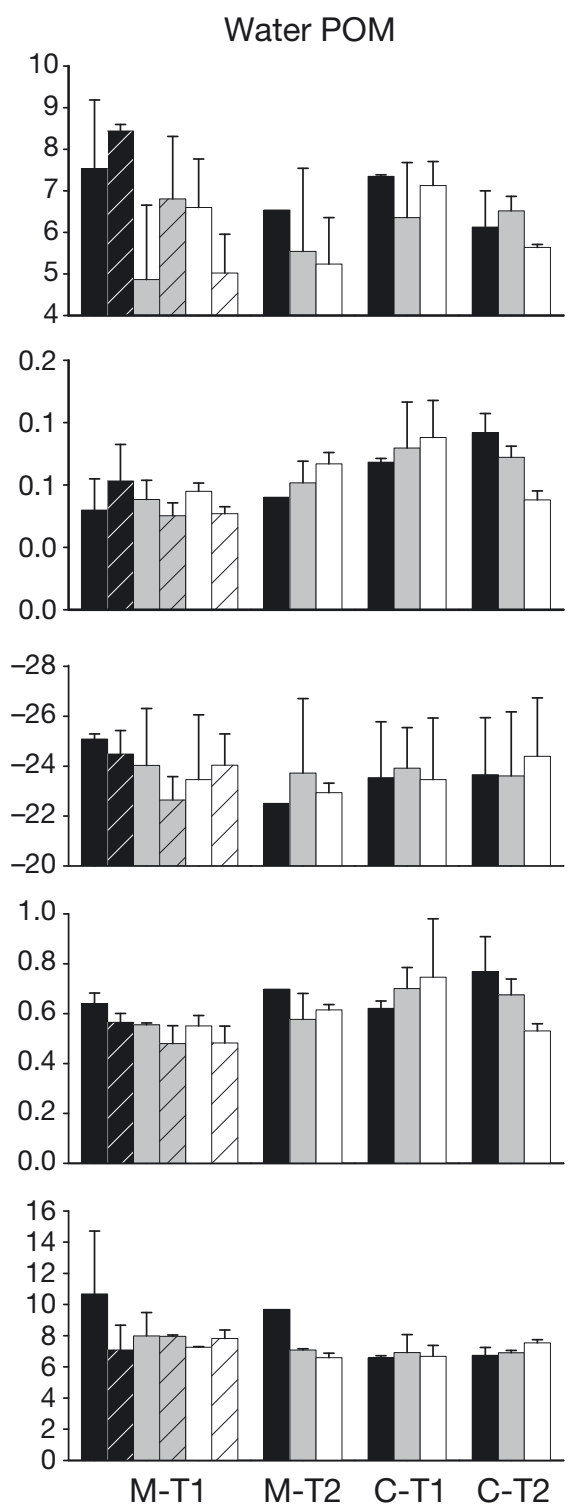

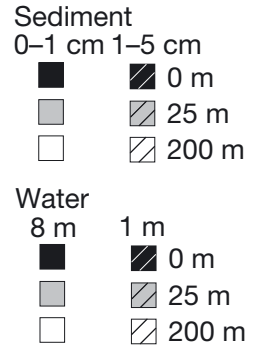

Fig. 2. $\delta^{15} \mathrm{~N}, \% \mathrm{~N}, \delta^{13} \mathrm{C}, \% \mathrm{C}$ and the $\mathrm{C} / \mathrm{N}$ ratio (mean + $\mathrm{SD}, \mathrm{n}=2$ ) of the sediment organic matter (2 layers) and of the water particular organic matter (POM) (at 2 depths) sampled at the salmon farms Millstone (M) and Cranford (C) in Aug 2009. Sediment and water samples were collected at 3 stations $(0,25$ and $200 \mathrm{~m}$ from the farms) along each of 2 transects (perpendicular [T1] and parallel [T2] to the current). Horizontal lines over bars indicate groups that are not significantly different (Tukey's pairwise comparison, $p>0.05$ ). When no lines are shown, there are no significant differences. Note some $y$-axes do not start at 0 
intermediate between salmon feed pellets, faeces and algae for $\delta^{13} \mathrm{C}$, but depleted in ${ }^{15} \mathrm{~N}$, probably because cage deposits may include salmon faeces, uneaten feed pellets as well as faeces from fouling organisms and macroalgae detritus. Algae (Fucus sp., Laminaria sp., Ulva spp.) sampled in Mulroy Bay at sites located $>2 \mathrm{~km}$ from the farms (Fig. 1) were enriched in ${ }^{13} \mathrm{C}$ and depleted in ${ }^{15} \mathrm{~N}$ compared to farm sources of organic matter (OM).

\section{Sediment OM and water POM analysis}

Overall, no clear pattern was observed in either sediment or water characteristics (Fig. 2). Sediment $\delta^{15} \mathrm{~N}, \% \mathrm{~N}, \delta^{13} \mathrm{C}, \% \mathrm{C}$ and $\mathrm{C} / \mathrm{N}$ did not differ among distances $(0,25$ and $200 \mathrm{~m})$, directions (parallel vs. perpendicular to water current) or depths (0 to $1 \mathrm{~cm}$ vs. 1 to $5 \mathrm{~cm})$. Average $( \pm \mathrm{SD})$ sediment $\% \mathrm{C}, \% \mathrm{~N}$ and $\mathrm{C} / \mathrm{N}$ were higher at Cranford farm $(2.5 \pm 0.6 \%, 0.4 \pm$ $0.1 \%$ and $6.7 \pm 0.7$, respectively) than at Millstone farm $(0.7 \pm 0.5 \%, 0.1 \pm 0.1 \%$ and $5.6 \pm 0.9$, respectively) ( $\mathrm{p}<0.005$, Fig. 2). Averaged for the 2 farms, $\delta^{15} \mathrm{~N}$ and $\delta^{13} \mathrm{C}$ were $6.5 \pm 0.4 \%$ and $-21.2 \pm 0.5 \%$, respectively. Although variation in water POM isotopic values did not differ significantly in relation to farm, distance, direction, or depth, slightly higher $\delta^{15} \mathrm{~N}$ were observed at Millstone under the cages ( $0 \mathrm{~m}$ ) compared to 25 and $200 \mathrm{~m}$ away from them (Fig. 2). The C/N of water POM (maximum: $10.6 \pm 4$ ) was also slightly higher at the Millstone $0 \mathrm{~m}$ station.

\section{Benthic community}

A total of 63 macrofaunal species were identified at Millstone and Cranford farms. At both farms, a lower
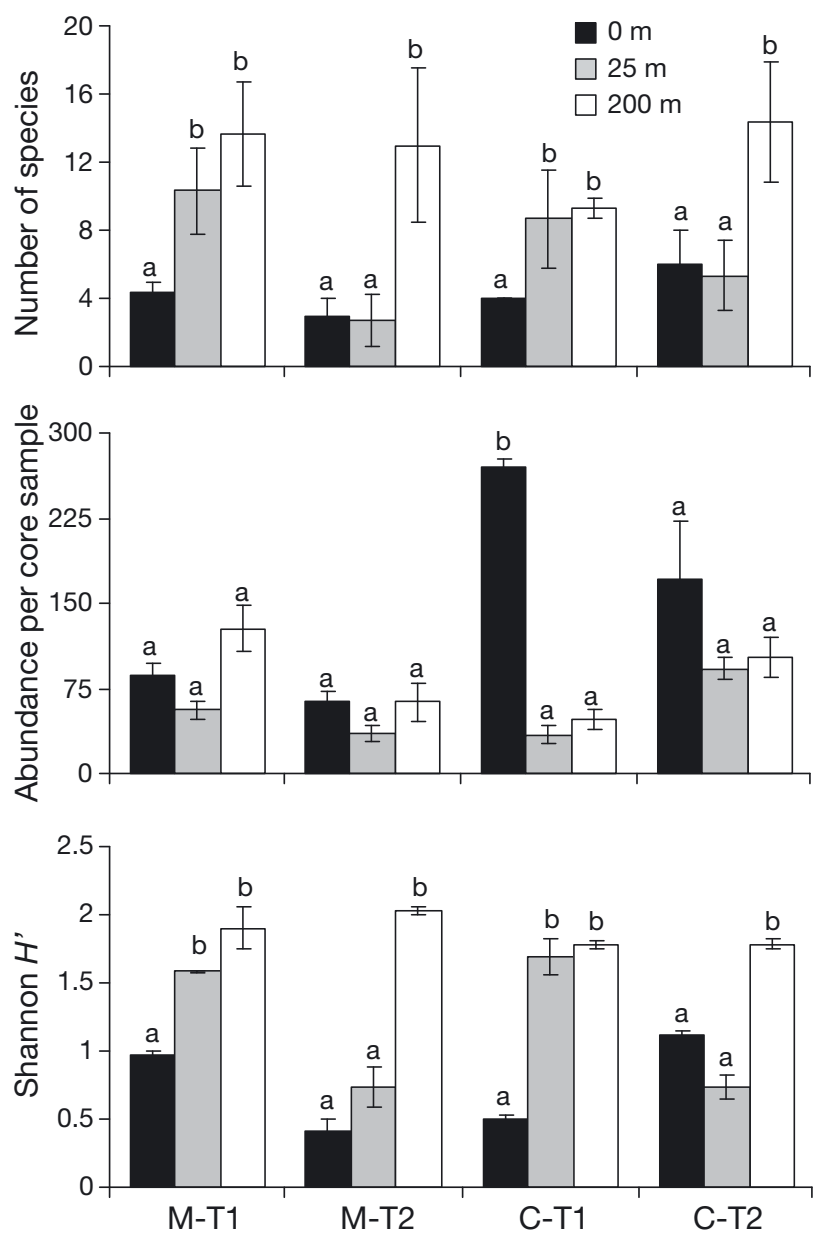

Fig. 3. Number of benthic species, total abundance and Shannon diversity index $\left(H^{\prime}\right)$ per core sample (mean $\pm \mathrm{SD}$, $\mathrm{n}=3$, corer surface $=105.7 \mathrm{~cm}^{2}$ ) at Millstone $(\mathrm{M})$ and Cranford (C) farms, at 3 stations $(0,25$ and $200 \mathrm{~m}$ from the farms) along each of 2 transects (perpendicular [T1] and parallel [T2] to the current) in July 2009. See Table 2 for ANOVA results. Significant differences among groups as identified by Student-Newman-Keuls pairwise contrasts are indicated by different letters above bars

Table 2. ANOVA results for benthic macrofaunal characteristics (number of species, total abundance, Shannon-Wiener diversity $\left.\left[H^{\prime}\right]\right)$ observed at 2 salmon farms. Fixed factors were farm (FA; Millstone and Cranford), direction (DIR; perpendicular and parallel to the main water current) and distance (DIS; 0, 25 and $200 \mathrm{~m}$ from the salmon cages). Bold: significant (p $\leq 0.05$ )

\begin{tabular}{|c|c|c|c|c|c|c|c|c|c|c|}
\hline \multirow{2}{*}{$\begin{array}{l}\text { Sources of } \\
\text { variations }\end{array}$} & \multirow[t]{2}{*}{ df } & \multicolumn{3}{|c|}{ - Number of species } & \multicolumn{3}{|c|}{ — Total abundance $ـ$} & \multicolumn{3}{|c|}{$-H^{\prime}-$} \\
\hline & & MS & $F$ & $\mathrm{p}$ & MS & $F$ & $\mathrm{p}$ & MS & $F$ & $\mathrm{p}$ \\
\hline FA & 1 & 0.028 & 0 & 0.945 & 20164 & 6.27 & 0.019 & 0.009 & 0.12 & 0.733 \\
\hline DIR & 1 & 8.028 & 1.41 & 0.247 & 2272.11 & 0.71 & 0.409 & 0.826 & 11.06 & 0.003 \\
\hline DIS & 2 & 214.750 & 37.71 & $<0.001$ & 27346.08 & 8.5 & 0.002 & 3.893 & 52.11 & $<0.001$ \\
\hline $\mathrm{FA} \times \mathrm{DIR}$ & 1 & 42.250 & 7.42 & 0.012 & 3680.44 & 1.14 & 0.299 & 0.335 & 4.48 & 0.045 \\
\hline $\mathrm{FA} \times \mathrm{DIS}$ & 2 & 6.194 & 1.09 & 0.353 & 22481.58 & 6.99 & 0.004 & 0.102 & 1.37 & 0.273 \\
\hline DIR $\times$ DIS & 2 & 45.986 & 8.05 & 0.002 & 5095.03 & 1.58 & 0.226 & 1.128 & 15.1 & $<0.001$ \\
\hline $\mathrm{FA} \times \mathrm{DIR} \times \mathrm{DIS}$ & 2 & 1.083 & 0.19 & 0.828 & 8172.53 & 2.54 & 0.099 & 0.723 & 4.84 & 0.017 \\
\hline Residual & 24 & 5.694 & & & 3218.16 & & & 1.793 & & \\
\hline
\end{tabular}


diversity (number of species and Shannon $H^{\prime}$ ) was observed under the cages ( $0 \mathrm{~m}$ stations) compared to the stations $200 \mathrm{~m}$ from the cages in both water current directions (Fig. 3). Diversity at $25 \mathrm{~m}$ was either similar to diversity at $0 \mathrm{~m}$ along the dominant current direction transect or similar to $200 \mathrm{~m}$ sites along the transect perpendicular to the dominant water current (Table 2). Therefore, at both farms, the extent of the effect on diversity was $<25 \mathrm{~m}$ when perpendicular to the main water current and $>25 \mathrm{~m}$ but $<200 \mathrm{~m}$ along the main current direction. Macrofaunal abundances did not vary significantly with distance from cages (Fig. 3), except under Cranford cages (C-T1-0 m), which exhibited a particularly high abundance of Capitella sp.

Community structure analysis, based on abundance, revealed 2 distinct clusters (Fig. 4; PERMANOVA, $p<0.05)$. The first cluster included the $0 \mathrm{~m}$ stations and $25 \mathrm{~m}$ T2 stations (i.e. along the main current direction) at both Millstone and Cranford farms. SIMPER analysis indicated that Cluster 1 was characterised by 3 dominant species: Capitella capitata, Malacoceros fuliginosus and Tubificoides sp., with particularly high abundance of C. capitata under Cranford cages (up to 252 ind. core $^{-1}$, corresponding to 26517 ind. $\mathrm{m}^{-2}$ ) and high abundance of $M$. fuliginosus under Millstone cages (66 ind. core $^{-1}$, corresponding to 6945 ind. $\mathrm{m}^{-2}$ ). The second cluster included the $200 \mathrm{~m}$ stations and the $25 \mathrm{~m}$ T1 stations (i.e. perpendicular to the main water current direction). Contrary to Cluster 1, Cluster 2 was characterised by very low abundance of $C$. capitata and $M$. fuliginosus, and a more diverse community. Furthermore Cluster 2 exhibited subdivisions between stations: The communities located at $25 \mathrm{~m}$ from Millstone and $200 \mathrm{~m}$ from Millstone and Cranford were characterised by the presence of Maldanidae, Heteromastus filiformis, Lumbrineris gracilis, the bivalve Tellimya ferruginosa and the holothurid Leptosynapta inhaerens. Dissimilarity between the Cranford $25 \mathrm{~m}$ station (T1) and the other stations of Cluster 2 was largely related to the presence of Galathowenia oculata and Polydora sp. in samples from the former station.
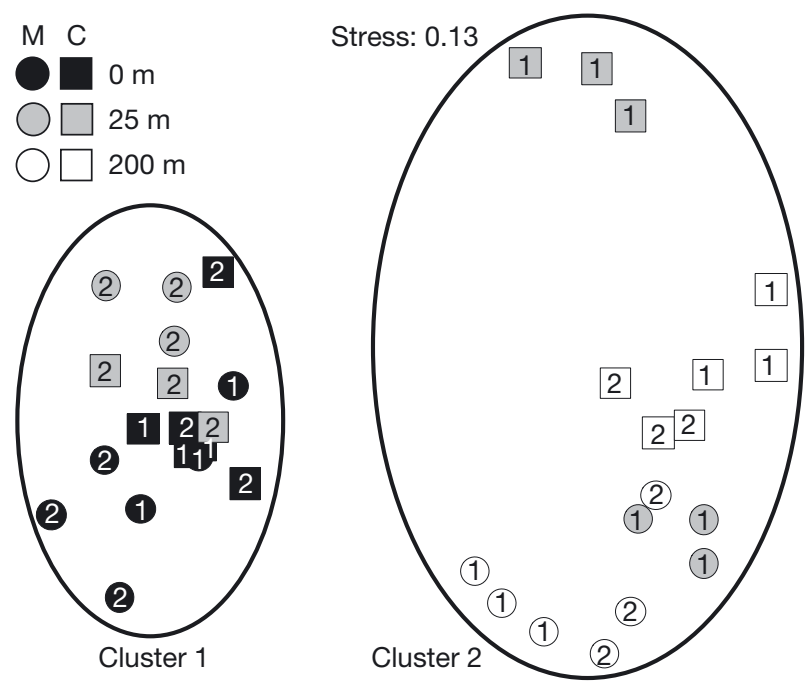

Fig. 4. Non-metric multi-dimensional scaling illustrating variation in benthic community structure (using squareroot-transformed abundance data) near 2 salmon farms: Millstone (M) and Cranford (C). Benthic samples were collected in July 2009 at 3 stations $(0,25$ and $200 \mathrm{~m}$ from the farms) along 2 transects (perpendicular [1] and parallel [2] to the current)

\section{Trophic groups and M-AMBI}

Of the 63 species observed, 32 were surface/subsurface deposit-feeders (e.g. Capitella sp., Malacoceros fuliginosus), 9 were suspension-feeders (e.g. Tellimya ferruginosa) and 12 were carnivores (e.g.

Table 3. Trophic group composition of benthic communities, biotic index classification (AMBI and M-AMBI) and ecological status at Millstone (M) and Cranford (C) farms. Samples were collected at 3 stations $(0,25$ and 200 $\mathrm{m}$ from the farms) along each of 2 transects (perpendicular T1 and parallel T2 to the current) in July 2009. Df: deposit-feeder; Sf: suspension-feeders; Car: carnivores; H: herbivores; O: omnivores. The trophic group of a few species was undetermined (max. $7 \%$ per station). AMBI and M-AMBI are based on the sensitivity/tolerance level of species to organic enrichment. (-) no species found belonging to that trophic group

\begin{tabular}{|c|c|c|c|c|c|c|c|c|}
\hline \multirow[t]{2}{*}{ Station } & \multicolumn{5}{|c|}{-Abundance (\%)- } & \multicolumn{3}{|c|}{$\longrightarrow$ Biotic index -} \\
\hline & Df & $\mathrm{Sf}$ & Car & $\mathrm{H}$ & $\mathrm{O}$ & AMBI & M-AMBI & Status \\
\hline M-T1-0 & $99 \pm 1$ & - & - & - & - & 6.0 & 0.2 & Poor \\
\hline M-T1-25 & $88 \pm 10$ & $9 \pm 10$ & $2 \pm 2$ & - & $0 \pm 1$ & 1.1 & 0.9 & High \\
\hline M-T1-200 & $65 \pm 22$ & $25 \pm 20$ & $9 \pm 3$ & $1 \pm 1$ & $0 \pm 1$ & 3.4 & 0.9 & High \\
\hline M-T2-0 & $99 \pm 1$ & - & - & - & - & 6.0 & 0.1 & Bad \\
\hline M-T2-25 & $95 \pm 5$ & $3 \pm 6$ & $2 \pm 3$ & - & - & 5.8 & 0.1 & Bad \\
\hline M-T2-200 & $45 \pm 7$ & $44 \pm 3$ & $9 \pm 11$ & - & $2 \pm 2$ & 1.4 & 1.0 & High \\
\hline C-T1-0 & $100 \pm 0$ & $0 \pm 0$ & - & - & - & 6.0 & 0.2 & Bad \\
\hline C-T1-25 & $67 \pm 28$ & $7 \pm 5$ & $19 \pm 19$ & - & - & 3.2 & 0.7 & Good \\
\hline C-T1-200 & $65 \pm 7$ & $5 \pm 5$ & $29 \pm 9$ & - & - & 1.5 & 0.9 & High \\
\hline C-T2-0 & $95 \pm 6$ & $0 \pm 1$ & $1 \pm 1$ & - & - & 5.8 & 0.3 & Poor \\
\hline C-T2-25 & $99 \pm 1$ & $0 \pm 1$ & $0 \pm 0$ & - & - & 5.9 & 0.3 & Poor \\
\hline C-T2-200 & $40 \pm 13$ & $40 \pm 9$ & $18 \pm 9$ & - & $1 \pm 1$ & 1.4 & 0.9 & High \\
\hline
\end{tabular}


Lumbrineris gracilis, Ophiocomina nigra) (Table 3). Benthic communities of Cluster 1 (i.e. 0 m-T1, $0 \mathrm{~m}-\mathrm{T} 2,25 \mathrm{~m}-\mathrm{T} 2$ at both farms) were almost exclusively dominated by deposit-feeders (95 to $100 \%$ ). The benthic status at those stations was classified as poor/bad by M-AMBI (Table 3). Stations in Cluster 2 were characterised by more diverse trophic groups, with the proportion of suspension feeders varying from 5 to $44 \%$ and carnivores from 2 to $29 \%$ (Table 3). The benthic status of the Cluster 2 station was classified as good/high by M-AMBI.

Based on the benthic community analysis, 2 conditions were observed at Millstone and Cranford farms: communities that were highly impacted by the salmon farms and communities that were not or only slightly impacted by the farms. We hypothesized that species assimilating salmon waste as a food source will present different isotopic signatures at impacted versus non-impacted sites.
Impacted

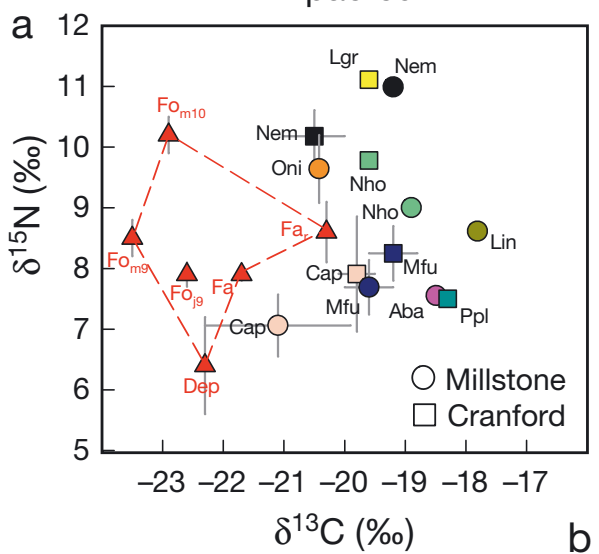

Non-impacted
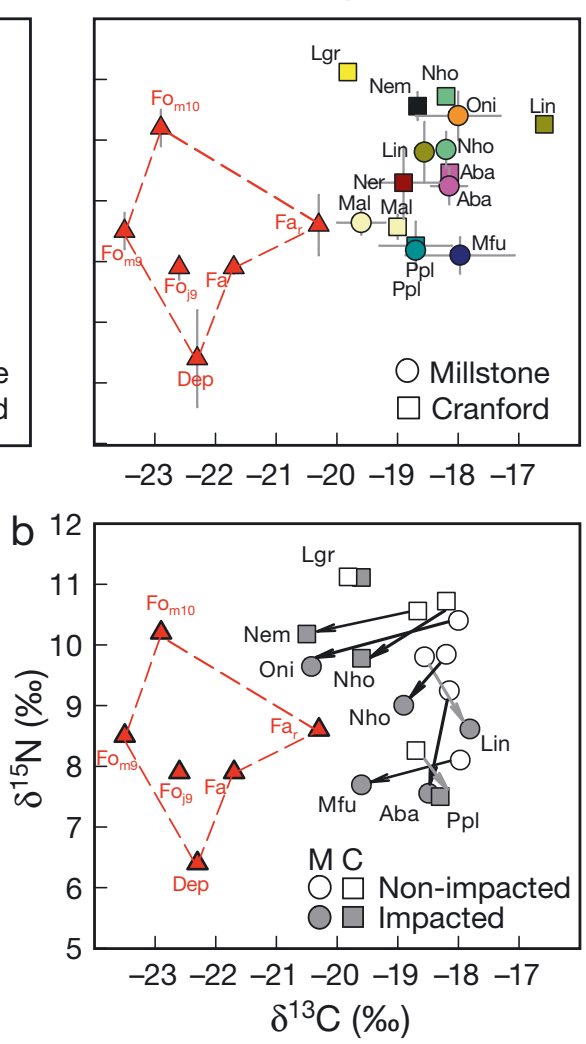

Fig. 5. (a) Interspecific and (b) intraspecific variation of mean $( \pm S D$, only shown in [a]) stable isotopic ratios in benthic species sampled at sites impacted (poor/bad biotic index status; see Table 3 for site status) or non-impacted (good/high status) by salmon waste at Millstone (M) and Cranford (C) farms. Red polygons represent the farm waste isotopic values for fish feed pellets collected in March 2009, June 2009 and May 2010 ( $\mathrm{FO}_{\mathrm{m} 9}, \mathrm{FO}_{j 9}$ and $\mathrm{FO}_{\mathrm{m} 10}$, respectively); deposits collected beneath cages (Dep); faeces with mucus $(\mathrm{Fa})$; and faeces without mucus $\left(\mathrm{Fa}_{\mathrm{r}}\right)$

\section{Inter- and intraspecific variations in isotopic signatures}

Interspecific variations in isotopic signature of the benthic organisms confirmed the trophic position of species within the community (Fig. 5a). At nonimpacted stations, at Millstone and Cranford, respectively, Maldanidae $\left(\delta^{15} \mathrm{~N}: 8.7 \%\right.$ and $\left.8.6 \%\right)$, Pherusa plumosa $\left(\delta^{15} \mathrm{~N}\right.$ : $8.2 \%$ and $8.3 \%$ ) and Malacoceros fuliginosus ( $\left(\delta^{15} \mathrm{~N}\right.$ : $8.1 \%$ in Millstone) presented lower $\delta^{15} \mathrm{~N}$, relative to the anemone Anthopleura balii $\left(\delta^{15} \mathrm{~N}\right.$ : $9.3 \%$ and $\left.9.5 \%\right)$, the polychaetes Nephtys hombergii $\left(\delta^{15} \mathrm{~N}\right.$ : $9.9 \%$ and $10.7 \%$ ) and Lumbrineris gracilis $\left(\delta^{15} \mathrm{~N}\right.$ : $11.2 \%$ in Cranford), the ophiuroids Ophiocomina nigra ( $\delta^{15} \mathrm{~N}$ : $10.4 \%$ in Millstone) and the holothurids Leptosynapta inhaerens $\left(\delta^{15} \mathrm{~N}\right.$ : $9.8 \%$ and $10.3 \%$ ). Nematoda had a similarly high $\delta^{15} \mathrm{~N}$ (10.6\% in Cranford).

At impacted stations, the 2 dominant deposit-feeders, Capitella capitata $\left(\delta^{15} \mathrm{~N}: 7.1 \%\right.$ and $\left.7.8 \%\right)$ and Malacoceros fuliginosus $\left(\delta^{15} \mathrm{~N}\right.$ : $7.7 \%$ and $8.0 \%$ ) presented low $\delta^{15} \mathrm{~N}$ as did the polychaetes Pherusa plumosa $\left(\delta^{15} \mathrm{~N}: 7.5 \%\right.$ in Cranford) and Anthopleura balii $\left(\delta^{15} \mathrm{~N}\right.$ : $7.5 \%$ in Millstone) (Fig. 5a). The polychaetes Nephtys hombergii $\left(\delta^{15} \mathrm{~N}\right.$ : $9.0 \%$ and $9.8 \%$ ) and Lumbrineris gracilis $\left(\delta^{15} \mathrm{~N}: 11.1 \%\right.$ in Cranford), the ophiuroids Ophiocomina nigra ( $\delta^{15} \mathrm{~N}$ : $9.6 \%$ in Millstone), the holothurids Leptosynapta inhaerens $\left(\delta^{15} \mathrm{~N}\right.$ : $8.6 \%$ in Millstone) and the Nematoda $\left(\delta^{15} \mathrm{~N}\right.$ : $10.1 \%$ and $11.0 \%$ ) were enriched in $\delta^{15} \mathrm{~N}$ compared to Capitella sp. and M. fuliginosus.

Intraspecific variation observed for several species between impacted (poor/bad benthic status) and nonimpacted stations (good/high benthic status) (Fig. 5b) allowed us to detect variation in the assimilation of food by these species. Among these species, a clear shift in isotopic values towards the farm waste values was observed in Malacoceros fuliginosus, Nephtys hombergii, Ophiocomina nigra and Nematoda. Those species collected at impacted stations were depleted in ${ }^{13} \mathrm{C}$ relative to conspecifics collected at non-impacted stations (variation of $2 \%$ in $\delta^{13} \mathrm{C}$ ). Slight interspecific variations in $\delta^{15} \mathrm{~N}$ $(<1 \%)$ were observed for species 
sampled at impacted vs. non-impacted sites; this variation was more pronounced for $N$. hombergii (Fig. 5b). Pherusa plumosa and Leptosynapta inhaerens had lower $\delta^{15} \mathrm{~N}$ at impacted than at non-impacted sites but were the only species with higher $\delta^{13} \mathrm{C}$. No variation was observed for Lumbrinereis gracilis.

Intraspecific variation in isotopic values was also observed for fouling communities on sampling tiles (Fig. 6). After 2 mo, the early colonizing community was dominated in terms of biomass by the solitary tunicate Ascidiella aspersa, colonial tunicate Diplosoma sp. and filamentous alga Enteromorpha sp. Mytilus edulis, hydroids and gastropod larvae were also present, but in very low abundance. The tunicates $A$. aspersa and Diplosoma sp. showed relatively little variation $\left(\sim 1 \% \delta^{13} \mathrm{C}\right)$ (Fig. 6). A. aspersa and the colonial tunicates at the $0 \mathrm{~m}$ station were enriched in ${ }^{15} \mathrm{~N}\left(\delta^{15} \mathrm{~N}\right.$ mean $\left.\pm \mathrm{SD}: 8.2 \pm 0.5 \%\right)$ relative to those at the $200 \mathrm{~m}$ station $\left(\delta^{15} \mathrm{~N}: 7.6 \pm 0.1 \%\right.$ ), while no significant difference in isotopic values was observed for fouling algae (Fig. 6).

\section{DISCUSSION}

We observed a gradient of organic enrichment around the studied fish farms such that benthic communities were strongly impacted by the farms (low diversity, dominance of opportunistic species) at some distances and orientations, whereas other communities were not or were only slightly impacted by the farms (higher diversity, presence of sensitive species). Stable isotope analysis supports the hypothesis that fish farm effluents contributed to the diets of several benthic and fouling organisms present in the vicinity of the farms.

\section{Potential source of nutrients}

Isotopic analysis $\left(\delta^{15} \mathrm{~N}, \delta^{13} \mathrm{C}\right)$ was used to track the fate of salmon-farm-related products (e.g. fish feed and waste) in the environment to determine if waste was used as a new source of food by adjacent biota (Yokoyama et al. 2006). Variation in isotopic signatures of the food sources was sufficient to identify variation in the organisms' diets. Effluent derived from salmon cages presented an isotopic composition that was distinct from other potential food sources (e.g. algae), and the point-source nature of the fish farm effluent reduced the confounding effects of mixed nutrient sources (Costanzo et al. 2003). As expected, fish feed pellets and faeces were enriched in ${ }^{15} \mathrm{~N}$ compared to

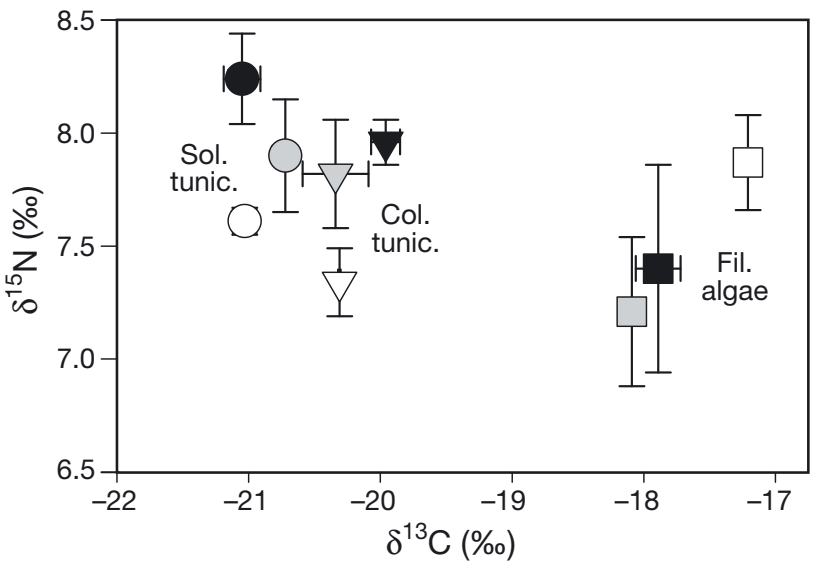

Fig. 6. Intraspecific variation of mean $( \pm \mathrm{SD}, \mathrm{n}=3)$ stable isotopic signatures of fouling organisms collected on suspended structures in June 2009 (6 tiles fixed on 3 structures per distance) placed $0 \mathrm{~m}$ (black), $25 \mathrm{~m}$ (grey) and $200 \mathrm{~m}$ (white) from cages, at Millstone salmon farm, perpendicular to the main water current direction. Data are pooled per structure (see 'Materials and methods') for the solitary tunicate Ascidiella aspersa, colonial tunicate Diplosoma sp. and filamentous alga Enteromorpha sp.

other organic matter sources such as macroalgae, as they were composed of fish and crustacean meal, and depleted in ${ }^{13} \mathrm{C}$, probably due to the presence of terrestrial vegetables (see 'Materials and methods') and fish oil in their composition (Yokoyama et al. 2006). Deposits collected within sediment traps placed under fish cages were depleted in ${ }^{15} \mathrm{~N}$ compared to feed pellets and faeces. This suggests that deposits were probably composed of a mixture of uneaten feed pellets, faeces and other material which may include faeces from fouling organisms, macroalgae etc. settling from the cages. However, caution should be taken with the interpretation of the deposit isotopic values, as these values only reflected $24 \mathrm{~h}$ of deposition.

High temporal variation was observed in the isotopic values of the fish feed pellets $\left(\delta^{15} \mathrm{~N}\right.$ varied from $7.9 \%$ in 2009 to $10.2 \%$ in 2010). Although food composition was similar, the fish meal and oil composing the pellets may have varied through time, as sources may differ over time, depending on wild fish supply. It is therefore important to consider seasonal variation in the stable isotope composition of fish feed pellets, as this may also change the isotopic value of both faeces and dissolved inorganic nitrogen. That being said, in the present study, fish feed pellets collected in March 2009 and June 2009, just before the organisms were sampled, presented similar isotopic compositions and were distinct from other food sources. Additionally, both farms were using the same pellet stock, which allows the findings from the 2 farms to be compared. 


\section{Fate of aquaculture waste in the environment}

Water column and sediment isotopic composition did not vary with distance from the fish cages (except for the water POM at $1 \mathrm{~m}$ depth). However, significant variation in isotopic values was observed in benthic organisms (see next subsection). This suggests a rapid incorporation of fresh settling material by the local biota, thus preventing the accumulation of POM in the sediment. This observation is in accordance with the observations made by Kon et al. (2009), who showed that, even though no changes could be found in the isotopic composition of the SOM, shrimp farming waste induced a food availability shift to aquaculture feed in benthic animals (fiddler crabs Uca annulipes, U. forcipata, and U. bengali). Kon et al. (2009) suggested that biological accumulation, i.e. the assimilation of organic matter by animals, is a better indicator than sediments. The lack of a clear sediment isotopic signal suggests that the proportion of labile OM in fish wastes was high. Lefebvre et al. (2000) showed that fish faeces were assimilated by suspension feeders with an absorption efficiency of $60 \%$. The low C/N ratios measured in fish feed pellets (7.9) confirmed the great nutritional value of fish waste.

\section{Benthic community characteristics and diet}

Abundance, diversity and community structure

At both studied farms, similar trends were observed in terms of variation in macrofaunal diversity and structure. The extent of measurable change in benthic communities was a function of residual current direction. Along the transect parallel to the main current direction, communities at 0 and $25 \mathrm{~m}$ sites were more similar to each other than those observed at $200 \mathrm{~m}$, suggesting that the extent of influence was between 25 and $200 \mathrm{~m}$. Along the transects perpendicular to the residual currents, the communities at a distance of $25 \mathrm{~m}$ were more similar to those at $200 \mathrm{~m}$ than to those directly under the farms. The current data combined with previous observations made at the Millstone and Cranford farms (Telfor \& Robinson 2003) suggest that the extent of influence in this direction was $<25 \mathrm{~m}$, which is consistent with previous studies considering the impacts of fish farming on benthic communities (Mazzola et al. 2000, Nickell et al. 2003, Kutti et al. 2007b).

Changes in benthic community structure and decreased diversity were observed under fish cages. Low diversity is consistent with the general pattern of community changes due to organic enrichment, as increasingly anoxic sediment favours the proliferation of organisms that can tolerate such conditions (Pearson \& Rosenberg 1978, Diaz \& Rosenberg 1995, Holmer et al. 2005). Indeed, increased sediment oxygen demand may lead to anoxia and higher sulphide concentration that may not be tolerated by certain species (Findlay et al. 1995, Pearson \& Black 2001, Kinoshita et al. 2008). At Millstone farm, no difference in total abundance was observed among distances, but at Cranford, the abundance of invertebrates was increased beneath the cages relative to other distances, indicating that tolerant species benefited from localized conditions, probably in response to increased food availability derived from the salmon cages (faeces, uneaten feed pellets, fouling), with a reduction of predators and competitors that are sensitive to high organic loading. Indeed, communities under salmon cages were dominated by deposit-feeders, whereas stations further away from the farm were dominated by carnivores and suspension-feeders, which are sensitive to organic loading. Species able to assimilate this new source of food and to tolerate new habitat conditions may have outcompeted species that were normally dominant.

Interspecific stable isotope variation

Interspecific variations in stable isotope values reveal the trophic position of each species composing the macrobenthic communities. At non-impacted sites, communities were diverse and were represented by species within a wide range of trophic levels, including deposit-feeders, suspension-feeders and predators. The lowest trophic level was represented by polychaete deposit-feeders of the family Maldanidae, Pherusa plumosa and Malacoceros fuliginosus. Species representing higher trophic levels included the anemone Anthopleura balii, the predatory polychaetes Nephtys hombergii and Lumbrineris gracilis and the ophiuroid Ophiocomina nigra (higher $\delta^{15} \mathrm{~N}$ ). Under the influence of salmon cages, communities were almost exclusively dominated by deposit-feeders that are able to thrive under high organic loading (Pearson \& Black 2001). The polychaetes Capitella capitata and $M$. fuliginosus became dominant and presented the lowest trophic level of the macrofaunal community (relatively low ${ }^{15} \mathrm{~N}$ ). C. capitata and $M$. fuliginosus are known to be tolerant to high organic loading (Cardell et al. 1999, Lindqvist et al. 2009). Part of their diet was probably composed of fish farm waste (as shown by the intraspecific variation in 
stable isotope values; see next subsection). Fish waste may have been incorporated by the deposit-feeders through direct or indirect assimilation (e.g. through the consumption of bacteria feeding on waste). $C$. capitata is a subsurface deposit-feeder that ingests sediment as it burrows, absorbing nutrients from the surfaces of sediment particles (Tsutsumi et al. 1990). C. capitata is often highly abundant in sediment enriched by organic material from detritic algae (Bolam et al. 2000), sewage (Tsutsumi 1990), mussel farming (Callier et al. 2007), or fish farming (Black 2001), and can reach very high abundances, depending on the quality and quantity of food. Tsutsumi et al. (2005) and Kinoshita et al. (2008) evaluated the capacity of $C$. capitata to bioremediate organically enriched sediment under fish cages by introducing mass-cultured colonies of C. capitata, and showed that populations could reach 400000 ind. $\mathrm{m}^{-2}$. M. fuliginosus are tentaculate (palp) surface deposit-feeders, which collect food particles directly from the substrate surface using their tentacles to carry food to their mouths, thus further supporting the hypothesis of a rapid incorporation of nutrients by the biota before accumulation into the sediments. Other less dominant species in communities at farm-impacted sites were omnivorous or predatory species. The polychaetes Nephtys hombergii presented a high trophic level (3.1 to 3.7) compared to C. capitata (2.6 to 2.8) and M. fuliginosus (2.8 to 2.9). N. hombergii, known to be a predator, was potentially feeding on the 2 deposit-feeders. However, considering the low abundance of $N$. hombergii, its influence on the population size of deposit-feeders was probably low. Similarly, the sea anemones Anthopleura balii represented a high trophic level (2.7 to 3.3). Part of their diet was probably composed of small polychaetes (C. capitata and M. fuliginosus). Anemones are known to be omnivores/predators; observation of gut contents confirmed the presence of polychaetes in their diet (M. Callier pers. obs.). Anemones also harbor photosynthetic endosymbionts (Davy \& Turner 2003). Nematodes presented a high trophic level and a different range of $\delta^{13} \mathrm{C}$ values compared to species at similar trophic levels. It is possible that nematodes feed on a different fraction of OM than do macrobenthic taxa, as suggested by Franco et al. (2008) and van Oevelen et al. (2009), or on the same sources but different proportions of OM.

Intraspecific stable isotope variation

Intraspecific variation in isotopic values in benthic invertebrates was mostly explained by farm-related effects. A significant shift in $\delta^{13} \mathrm{C}$ was observed for the polychaetes Malacoceros fuliginosus and Nephtys hombergii, for Nematoda and for the anemone Anthopleura balii. Individuals collected at impacted stations were depleted in ${ }^{13} \mathrm{C}$ relative to individuals collected from non-impacted stations. This is in accordance with other studies on the fate of aquaculture-related wastes evaluated using ${ }^{13} \mathrm{C}$ as a tracer (Kullman et al. 2009). This provides direct evidence that detritivorous species benefit from the higher organic loading from the salmon cages. With respect to predators, the decreased trophic level (lower $\delta^{15} \mathrm{~N}$ ) observed for $N$. hombergii indicates that they too may have assimilated salmon wastes as a new source of food when located under the cages. In non-impacted communities, the feeding mode of $N$. hombergii was mostly predatory, but under the fish cages the species may have acted as a deposit-feeder. This result supports the concept of small-scale trophic plasticity, in which consumers adapt to modifications of food availability (Pinnegar \& Polunin 2000), as observed in suspension-feeding invertebrates influenced by oyster biodeposition (Dubois et al. 2007a). It is also possible that the lower $\delta^{15} \mathrm{~N}$ may have induced a variation in its signature. Among the species collected at impacted and non-impacted sites, Lumbrineris gracilis did not show variation in isotopic signature, so it could be classified as a trophic specialist (Dubois et al. 2007b). Only a few species were present both under cages and at $200 \mathrm{~m}$ sites. It is therefore difficult to draw general conclusions about trophic plasticity in these communities. Moreover, an average trophic fractionation value of 3.4 was used, as this value has been shown to be correct in numerous studies (Post 2002). However, this value could differ among species. To better determine the trophic plasticity of benthic species, further studies are needed to determine specific isotopic fractionation values.

After 2 mo, the fouling community was dominated in terms of biomass by the solitary tunicate Ascidiella aspersa, colonial tunicate Diplosoma sp. and filamentous algae Ulva spp. Mytilus edulis, hydroids and gastropod recruits were also present but in very low abundance. Previous studies observed similar results considering fouling communities on pontoons and nets and showed that dominant species near salmon cages included hydroids, tunicates and bivalves (Cook et al. 2006, Rensel \& Forster 2007). The present study showed that $A$. aspersa, a filter-feeder, was enriched in ${ }^{15} \mathrm{~N}$ at farm sites. This result indicates that tunicates may efficiently filter and assimilate particulates from fish cages. As suggested by Lojen et al. (2005), considering the water current speed and 
distance of the substrates, the fouling community probably feeds on fresh fish farm effluent, whereas the benthic community further away may feed on altered faecal material, thus potentially modifying the $\delta^{15} \mathrm{~N}$ due to bacterial activity. Algae potentially assimilating the inorganic dissolved nutrients presented no clear difference in isotopic values between stations. This may be due to the faster dispersion of dissolved nutrients relative to POM (Lin \& Fong 2008).

\section{CONCLUSION}

Our study showed small-scale influences of salmon farms on benthic and fouling communities, with possible effects on trophic structure. Stable isotope composition was shown to be a powerful tool for tracing the fate of fish waste into the biota, allowing the assimilation of salmon waste by benthic species to be detected and thus showing that they shifted their diets to include this nutrient input. The study highlights the need to sample multiple sites in order to consider both inter- and intraspecific variability and to better determine the fate of aquaculture waste in the structure of the food web. Sedimentary and fouling organisms - potential sinks for fish effluents play an important role in the carrying capacity of ecosystems for aquaculture. Adapted husbandry practices, such as integrated multi-trophic aquaculture, could promote biomass of species able to assimilate fish waste and, therefore, dampen environmental impacts (Cook et al. 2006). However, further experiments are needed to confirm that adjacent biota can significantly reduce nutrient concentrations in the water column and sediments surrounding fish cages and effectively prevent aquaculture enclosures from organically enriching the surrounding environment.

Acknowledgements. We thank University College Dublin and University of Caen and especially the MARBEE team for their precious help during field work. Thanks to Francis O'Beirn (Marine Institute) and Grainne O'Brien (Bord Iascaigh Mhara) for advice and assistance. Thanks to Marine Harvest and Catherine McManus who kindly provided access to the farms. Thanks also to all the Mulroy Bay salmon farmers and divers who helped with the work. The manuscript has been improved thanks to the comments of Dr. C. W. McKindsey and 3 anonymous reviewers. This paper has been published as part of the SIMBIOSYS project (2007-B-CD-1-S1), part of the Science, Technology, Research and Innovation for the Environment (STRIVE) Programme 2007-2013. The programme is financed by the Irish Government under the National Development Plan 2007-2013; it is administered on behalf of the Department of the Environment, Heritage and Local Government by the Environmental Protection Agency which has the statutory function of co-ordinating and promoting environmental research.

\section{LITERATURE CITED}

Anderson MJ, Ter Braak CJF (2003) Permutation tests for multi-factorial analysis of variance. J Statist Comput Simulation 73:85-113

Black KD (2001) Environmental impacts of aquaculture. Sheffield Academic Press, Sheffield

> Bolam SG, Fernandes TF, Read P, Raffaelli D (2000) Effects of macroalgal mats on intertidal sandflats: an experimental study. J Exp Mar Biol Ecol 249:123-137

Borja A, Muxika I (2005) Guidelines for the use of AMBI (AZTI's Marine Biotic Index) in the assessment of the benthic ecological quality. Mar Pollut Bull 50:787-789

Callier MD, McKindsey CW, Desrosiers G (2007) Multi-scale spatial variations in benthic sediment geochemistry and macrofaunal communities under a suspended mussel culture. Mar Ecol Prog Ser 348:103-115

Callier MD, McKindsey CW, Desrosiers G (2008) Evaluation of indicators used to detect mussel farm influence on the benthos: two case studies in the Magdalen Islands, eastern Canada. Aquaculture 278:77-88

> Cardell MJ, Sarda R, Romero J (1999) Spatial changes in sublittoral soft-bottom polychaete assemblages due to river inputs and sewage discharges. Acta Oecol Int J Ecol 20:343-351

Clarke KR, Warwick RM (1994) Change in marine communities: an approach to statistical analysis and interpretation. Plymouth Marine Laboratory, Plymouth

Cook EJ, Black KD, Sayer MDJ, Cromey CJ and others (2006) The influence of caged mariculture on the early development of sublittoral fouling communities: a panEuropean study. ICES J Mar Sci 63:637-649

Costanzo S, O'Donohue M, Dennison W (2003) Assessing the seasonal influence of sewage and agricultural nutrient inputs in a subtropical river estuary. Estuar Coast Shelf Sci 26:857-865

> Cromey CJ, Nickell TD, Black KD (2002) Depomod-modelling the deposition and the biological effects of waste solids from marine cage farms. Aquaculture 214:211-239

> Davy SK, Turner JR (2003) Early development and acquisition of zooxanthellae in the temperate symbiotic sea anemone Anthopleura balii (Cocks). Biol Bull 205:66-72

Diaz RJ, Rosenberg R (1995) Marine benthic hypoxia: a review of its ecological effects and the behavioural responses of benthic macrofauna. Oceanogr Mar Biol Annu Rev 33:245-303

> Dolenec T, Lojen S, Kniewald G, Dolenee M, Rogan N (2007) Nitrogen stable isotope composition as a tracer of fish farming in invertebrates Aplysina aerophoba, Balanus perforatus and Anemonia sulcata in central Adriatic. Aquaculture 262:237-249

> Dubois S, Marin-Leal JC, Ropert M, Lefebvre S (2007a) Effects of oyster farming on macrofaunal assemblages associated with Lanice conchilega tubeworm populations: a trophic analysis using natural stable isotopes. Aquaculture 271:336-349

> Dubois S, Orvain F, Marin-Leal JC, Ropert M, Lefebvre S (2007b) Small-scale spatial variability of food partitioning between cultivated oysters and associated suspen- 
sion-feeding species, as revealed by stable isotopes. Mar Ecol Prog Ser 336:151-160

FAO (Food and Agriculture Organization) (2010) The state of world fisheries and aquaculture 2010. FAO, Rome

Fauchald K, Jumars PA (1979) The diet of worms: a study of polychaete feeding guilds. Oceanogr Mar Biol Annu Rev 17:193-284

> Findlay RH, Walting L, Mayer LM (1995) Environmental impact of salmon net-pen culture on Maine marine benthic communities: a case study. Estuaries 18:145-179

Franco MA, Soetaert K, Costa MJ, Vincx M, Vanaverbeke J (2008) Uptake of phytodetritus by meiobenthos using ${ }^{13} \mathrm{C}$ labelled diatoms and Phaeocystis in two contrasting sediments from the North Sea. J Exp Mar Biol Ecol 362:1-8

Hargrave BT (2003) Far-field environmental effects of marine finfish aquaculture. In: A scientific review of the potential environmental effects of aquaculture in aquatic ecosystems. Can Tech Rep Fish Aquat Sci 2450:1-35

Hargrave BT (ed) (2005) Environmental effects of marine finfish aquaculture. The handbook of environmental chemistry, Vol 5. Water pollution, Part M. Springer, Berlin

Herman PMJ, Middelburg JJ, Van de Koppel J, Heip CHR (1999) Ecology of estuarine macrobenthos. In: Advances in ecological research, Vol 29. Academic Press, San Diego, CA, p 195-240

Holmer M, Wildish DJ, Hargrave B (2005) Organic enrichment from marine finfish aquaculture and effects on sediment biogeochemical processes. In: Hargrave BT (ed) The handbook of environmental chemistry, Vol 5. Water pollution, Part M. Springer, Berlin, p 181-206

Hughes TP, Bellwood DR, Folke C, Steneck RS, Wilson J (2005) New paradigms for supporting the resilience of marine ecosystems. Trends Ecol Evol 20:380-386

Kinoshita K, Tamaki S, Yoshioka M, Srithonguthai S and others (2008) Bioremediation of organically enriched sediment deposited below fish farms with artificially mass-cultured colonies of a deposit-feeding polychaete Capitella sp. I. Fish Sci 74:77-87

Kon K, Kawakubo N, Aoki JI, Tongnunui P, Hayashizaki KI, Kurokura H (2009) Effect of shrimp farming organic waste on food availability for deposit feeder crabs in a mangrove estuary, based on stable isotope analysis. Fish Sci 75:715-722

Kullman MA, Kidd KA, Podemski CL, Paterson MJ, Blanchfield PJ (2009) Assimilation of freshwater salmonid aquaculture waste by native aquatic biota. Can J Fish Aquat Sci 66:1965-1975

Kutti T, Ervik A, Hansen PK (2007a) Effects of organic effluents from a salmon farm on a fjord system. I. Vertical export and dispersal processes. Aquaculture 262: 367-381

Kutti T, Hansen PK, Ervik A, Hoisaeter T, Johannessen P (2007b) Effects of organic effluents from a salmon farm on a fjord system. II. Temporal and spatial patterns in infauna community composition. Aquaculture 262: 355-366

> Lefebvre S, Barille L, Clerc M (2000) Pacific oyster (Crassostrea gigas) feeding responses to a fish-farm effluent. Aquaculture 187:185-198

$>$ Lefebvre S, Bacher C, Meuret A, Hussenot J (2001) Modeling approach of nitrogen and phosphorus exchanges at the sediment-water interface of an intensive fishpond system. Aquaculture 195:279-297

> Lefebvre S, Marin Leal JC, Dubois S, Orvain F and others (2009) Seasonal dynamics of trophic relationships among co-occurring suspension-feeders in two shellfish culture dominated ecosystems. Estuar Coast Shelf Sci 82: 415-425

> Lin DT, Fong P (2008) Macroalgal bioindicators (growth, tissue $N, \delta^{15} \mathrm{~N}$ ) detect nutrient enrichment from shrimp farm effluent entering Opunohu Bay, Moorea, French Polynesia. Mar Pollut Bull 56:245-249

Lindqvist S, Norling K, Hulth S (2009) Biogeochemistry in highly reduced mussel farm sediments during macrofaunal recolonization by Amphiura filiformis and Nephtys sp. Mar Environ Res 67:136-145

$>$ Lojen S, Spanier E, Tsemel A, Katz T, Eden N, Angel DL (2005) $\delta^{15} \mathrm{~N}$ as a natural tracer of particulate nitrogen effluents released from marine aquaculture. Mar Biol 148:87-96

Lorrain A, Savoye N, Chauvaud L, Paulet YM, Naulet N (2003) Decarbonation and preservation method for the analysis of organic $\mathrm{C}$ and $\mathrm{N}$ contents and stable isotope ratios of low-carbonated suspended particulate material. Anal Chim Acta 491:125-133

- Mayor DJ, Zuur AF, Solan M, Paton GI, Killham K (2010) Factors affecting benthic impacts at Scottish fish farms. Environ Sci Technol 44:2079-2084

> Mazzola A, Sarà G (2001) The effect of fish farming organic waste on food availability for bivalve molluscs (Gaeta Gulf, Central Tyrrhenian, Mediterranean): stable carbon isotopic analysis. Aquaculture 192:361-379

- Mazzola A, Mirto S, La Rosa T, Fabiano M, Danovaro R (2000) Fish-farming effects on benthic community structure in coastal sediments: analysis of meiofaunal recovery. ICES J Mar Sci 57:1454-1461

McKindsey CW, Thetmeyer H, Landry T, Silvert W (2006) Review of recent carrying capacity models for bivalve culture and recommendations for research and management. Aquaculture 261:451-462

Michener RH, Schell DM (1994) Stable isotope ratios as tracers in marine aquatic food webs. In: Lajtha $\mathrm{K}$, Michener RH (eds) Stable isotopes in ecology and environmental sciences. Blackwell Scientific, Oxford, p 138-157

> Modica A, Scilipoti D, La Torre R, Manganaro A, Sarà G (2006) The effect of mariculture facilities on biochemical features of suspended organic matter (southern Tyrrhenian, Mediterranean). Estuar Coast Shelf Sci 66:177-184

Muxika I, Borja À, Bald J (2007) Using historical data, expert judgement and multivariate analysis in assessing reference conditions and benthic ecological status, according to the European Water Framework Directive. Mar Pollut Bull 55:16-29

Nickell LA, Black KD, Hughes DJ, Overnell J and others (2003) Bioturbation, sediment fluxes and benthic community structure around a salmon cage farm in Loch Creran, Scotland. J Exp Mar Biol Ecol 285/286:221-233

Pearson TH, Black KD (2001) The environmental impacts of marine fish cage culture. In: Black KD (ed) Environmental impacts of aquaculture. Sheffield Academic Press, Sheffield, p 1-32

Pearson TH, Rosenberg R (1978) Macrobenthic succession in relation to organic enrichment and pollution of the marine environment. Oceanogr Mar Biol Annu Rev 16: 229-311

> Pinnegar JK, Polunin NVC (2000) Contributions of stable isotope data to elucidating food webs of Mediterranean rocky littoral fishes. Oecologia 122:399-409

Pitta P, Tsapakis M, Apostolaki ET, Tsagaraki T, Holmer M, Karakassis I (2009) 'Ghost nutrients' from fish farms are 
transferred up the food web by phytoplankton grazers. Mar Ecol Prog Ser 374:1-6

Post DM (2002) Using stable isotopes to estimate trophic position: models, methods, and assumptions. Ecology 83: 703-718

Rensel JE, Forster JRM (2007) Beneficial environmental effects of marine finfish mariculture. NOAA National Marine Fisheries Service, Office of Oceanic and Atmospheric Research, Washington, DC

Ryba SA, Burgess RM (2002) Effects of sample preparation on the measurement of organic carbon, hydrogen, nitrogen, sulfur, and oxygen concentrations in marine sediments. Chemosphere 48:139-147

Sarà G, Scilipoti D, Mazzola A, Modica A (2004) Effects of fish farming waste to sedimentary and particulate organic matter in a southern Mediterranean area (Gulf of Castellammare, Sicily): a multiple stable isotope study $\left(\delta^{13} \mathrm{C}\right.$ and $\left.\delta^{15} \mathrm{~N}\right)$. Aquaculture 234:199-213

Telfor T, Robinson K (2003) Environmental quality and carrying capacity for aquaculture in Mulroy Bay, Co. Donegal. Marine Environment and Health Series, No. 9. http://oar.marine.ie/handle/10793/1/browse?type=author \&order $=$ ASC \&rpp $=20 \&$ value $=$ Telfor $\% 2 \mathrm{C}+\mathrm{T} \quad$ (accessed April 2012)

Tsutsumi H (1990) Population persistence of Capitella sp. (Polychaeta; Capitellidae) on a mud flat subject to environmental disturbance by organic enrichment. Mar Ecol Prog Ser 63:147-156

Tsutsumi H, Fukunaga S, Fujita N, Sumida M (1990) Relationship between growth of Capitella sp. and organic enrichment of the sediment. Mar Ecol Prog Ser 63: $157-162$

Editorial responsibility: Jana Davis, Annapolis, Maryland, USA
Tsutsumi H, Kinoshita K, Srithongouthai S, Sato A and others (2005) Treatment of the organically enriched sediment below the fish farm with the biological activities of artificially mass-cultured colonies of a small deposit feeding polychaete, Capitella sp. I. Benth Res 60:25-38

van Oevelen D, Soetaert K, Franco MA, Moodley L, van Ijzerloo L, Vincx M, Vanaverbeke J (2009) Organic matter input and processing in two contrasting North Sea sediments: insights from stable isotope and biomass data. Mar Ecol Prog Ser 380:19-32

Vizzini S, Mazzola A (2004) Stable isotope evidence for the environmental impact of a land-based fish farm in the western Mediterranean. Mar Pollut Bull 49:61-70

Vizzini S, Mazzola A (2006) The effects of anthropogenic organic matter inputs on stable carbon and nitrogen isotopes in organisms from different trophic levels in a southern Mediterranean coastal area. Sci Total Environ 368:723-731

Word JQ (1990) The infaunal trophic index, a functional approach to benthic community analyses. $\mathrm{PhD}$ dissertation, the University of Washington, Seattle, WA

- Yokoyama H, Ishihi Y (2007) Variation in food sources of the macrobenthos along a land-sea transect: a stable isotope study. Mar Ecol Prog Ser 346:127-141

> Yokoyama H, Abo K, Ishihi Y (2006) Quantifying aquaculture-derived organic matter in the sediment in and around a coastal fish farm using stable carbon and nitrogen isotope ratios. Aquaculture 254:411-425

Yokoyama H, Takashi T, Ishihi Y, Abo K (2009) Effects of restricted feeding on growth of red sea bream and sedimentation of aquaculture wastes. Aquaculture 286: 80-88

Submitted: December 13, 2011; Accepted: January 7, 2013 Proofs received from author(s): May 7, 2013 